\title{
Cytotoxic impacts of escin via inducing apoptosis and morphological changes on human prostate cancer cells
}

\author{
Canan VEJSELOVA SEZER *1 \\ ORCID: 0000-0002-3792-5993
}

\author{
${ }^{1}$ Eskişehir Technical University, Faculty of Science, Department of Biology, 26470, Eskişehir, Turkey
}

\begin{abstract}
Prostate cancer is one of the most prevalent cancer types in males with a percentages of $28 \%$ worldwide. This cancer type comprises approximately $37 \%$ of the cancer incidences in males in Turkey. Recent cancer investigations are focused on natural agents with good potent for cancer therapy. Escin is one of the most investigated agents of that kind but its effects on human prostate cancer cell's morphology is not investigated in detail, yet. Thus, the aim of this study is to investigate the antiproliferative, cytotoxic and proapoptotic effects of escin, on prostate cancer cells Du-145. Cytotoxicity of escin on prostate cancer cells was intestigated by using sulforhodamine B (SRB) assay and viability percentages and $\mathrm{IC}_{50}$ value were detected from the elisa reader (BioTek Synergy HTX) results. For morphological changes, Du-145 cells treated with the $\mathrm{IC}_{50}$ value of escin were evaluated under a confocal microscope (Leica, TCS SP5 II, Germany). Apoptosis profiles of cells were investigated by flow cytometry. According to the SRB findings escin reduced the viability of prostate cancer cells in dose-dependent manner and the $\mathrm{IC}_{50}$ value was detected as $30.48 \mu \mathrm{M}$ for 24 hours. On the confocal microscopy results it was confirmed that escin significantly changed the morphology of the treated cells as disintegrated and deformed nuclei, chromatin condensation, fragmentations in the cytoskeleton also shrinkage of prostate cells. Annexin-V technique indicated the apoptotic cell death trigered by escin in Du-145 cells. Based on the study results, it was concluded that escin changed the morphology of prostate cancer cells and induced apoptosis on prostate cancer cells.
\end{abstract}

Keywords: escin, cytotoxicity, prostate cancer

\section{İnsan prostat kanseri hücreleri üzerinde escinin apoptozis ve morfolojik değişiklikleri tetikleyici sitotoksik etkileri}

\section{Özet}

Prostat kanseri, dünya çapında \% 28'lik bir oranla erkeklerde en sık görülen kanser türlerinden biridir. Bu kanser türü, Türkiye'de erkeklerde görülen kanser vakalarının yaklaşık \% 37'sini oluşturmaktadır. Son kanser araştırmaları, kanser tedavisi için potansiyele sahip doğal ajanlara odaklanmıştır. Escin, bu özelliğinden dolayı en çok araştırılan ajanlardan biridir, ancak insan prostat kanseri hücresinin morfolojisi üzerindeki etkileri henüz ayrıntılı olarak araştırılmamıştır. $\mathrm{Bu}$ nedenle, bu çalışmanın amacı escinin Du-145 insan prostat kanseri hücreleri üzerindeki antiproliferatif, sitotoksik ve proapoptotik etkilerini araştırmaktır. Esinin prostat kanseri hücreleri üzerindeki sitotoksisitesi sulforhodamine B (SRB) testi ile incelenmiştir ve eliza plaka okuyucu (BioTek Synergy HTX) sonuçlarından canlılık yüzdeleri ve $\mathrm{IC}_{50}$ değeri saptanmıştır. Morfolojik değişiklikler için escinin $\mathrm{IC}_{50}$ değeri ile inkübe edilmiş olan Du-145 hücreleri, bir konfokal mikroskop (Leica, TCS SP5 II, Almanya) altında değerlendirilmiştir. Hücrelerin apoptotik profilleri akış sitometrisi ile araştırılmıştır. SRB bulgularına göre escin, prostat kanseri hücrelerinin canlılığını doza bağlı olarak azaltmış ve $\mathrm{IC}_{50}$ değeri 24 saat için $30,48 \mu \mathrm{M}$ olarak tespit edilmiştir. Konfokal mikroskopi sonuçlarında, escin ile muamele edilmiş hücrelerin morfolojisinde, parçalanmış ve deforme olmuş çekirdekler, kromatin yoğunlaşması, hücre iskeletindeki fragmantasyonlar ve hücre büzüşmesi şeklinde önemli değişiklikler saptanmıştır. Anneksin-V tekniği, Du-145 hücrelerinde escinin apoptotik hücre ölümünü tetiklediğini

\footnotetext{
* Corresponding author / Haberleşmeden sorumlu yazar: Tel.: +905412598747; Fax.: +90 22232049 10; E-mail: cananveyselova@ gmail.com

(C) Copyright 2021 by Biological Diversity and Conservation $\quad$ Received: 28.02.2021; Published: 15.04.2021 
göstermiştir. Çalışma sonuçlarına bakıldığında, escinin insan prostat kanseri hücrelerinde sitotoksik etki göstererek morfolojik değişikliklere neden olduğu ve apoptozisi indüklediği saptanmıştır.

Anahtar kelimeler: escin, sitotoksisite, prostat kanseri

\section{Introduction}

Aesculus hippocastanum is a beautiful plant grown worldwide and known as horse chesnut tree. The horse chesnut tree has resistance to harsh environmental conditions [1]. It has wide range of usage from decoration to medicinal purposes [2]. The extracts of varying parts of horse chesnut tree have been used traditionally for the treatment of various diseases like rheumatism, gastrointestinal diseases and haemorrhoids as well as venous insufficiency disease and edema. The multipurpose properties of horse chesnut are attributed to its board range ingredients like escin, quercetin, kaempherol, fraxin and esculin [3]. Escin of the ingredients is reported as the main active substance imply to the therapeutic activities. The synonym of escin is polyhydroxyolean-12-ene 3-omonodesmosides and it has two different forms, alpha and beta [1]. $\beta$-escin has been reported as more active form of escin and it is used in the pharmaceuticals [4]. Beneficial properties like anti-inflammatory, anti-edematous, venous contractile, hypoglycaemic and anti-obesity activity make escin preferable and useful in medical and aesthetic fields [5-8]. Additionally, studies imply to use of escin as an anticancer agent in vitro and in vivo [9]. This active triterpenoid saponin, as an ingredient of Aesculus hippocastanum seed extract, has been highly investigated for its biological properties as well as anticancer potency [10]. The antioxidant and biological effects of escin is investigated in many cancer cells [11-13]. Also, several in vivo studies have reported the anti-tumor and anti-inflammatory potentials of escin. In this study were examined potential cytotoxic and proapoptotic effects of escin on human prostate cancer (Du-145) cells as a model of prostate cancer that is the most common cancer in men as well as the main cause of the high mortality rates in cancer dependent deaths worldwide.

\section{Materials and methods}

\subsection{Materials}

Du-145 cells were purchased from the American Type Culture Collection (Manassas, USA). Escin, Sulphorodamin B, fetal bovine serum, penicillin-streptomycin were from Sigma-Aldrich (St. Louis, USA), and RPMI1640 was obtained from GIBCO (Grand Island, USA). Annexin-V and Dead Cell Assay Kit was purchased from (Merck, Millipore, Hayward, California, USA).

\section{2. $\quad$ Sulphorodamin B viability assesment}

Sulforhodamine B (SRB) assay was performed for testing the cytotoxicity of escin on prostate cancer cells. Briefly, Du-145 prostate cancer cells $\left(5 \times 10^{3}\right.$ cells/well) were seeded on 96 -well plates for $24 \mathrm{~h}$. Incubated cells were treated with various concentrations $(1,56-100 \mu \mathrm{M})$ of escin for 24 hours. After the incubation cells were washed in icecold phosphate-buffered saline (PBS), fixed with trichloroacetic acid (TCA) $\left(10 \%\right.$ in PBS) and incubated at $4{ }^{\circ} \mathrm{C}$ for 24 hours. Then, cells were washed with distilled water and dried. Cells were incubated with SRB (50 $\mu \mathrm{L} /$ well $)$ in the dark for $45 \mathrm{~min}$ at room temperature. After incubation cells were washed with acetic acid $(200 \mu \mathrm{L})(1 \%)$ and allowed to air for $30 \mathrm{~min}$. $200 \mu \mathrm{L} /$ well of Tris-base $(10 \mathrm{mM}, \mathrm{pH} 10,5)$ was added and cells were incubated for 1 hours at room temperature. After the incubation absorbances were read on an elisa reader (BioTek Synergy HTX) at $540 \mathrm{~nm}$. Viability percentages were calculated compared to the control cells and the $\mathrm{IC}_{50}$ value was determined based on the viability percentages. Statistical significances were determined by using one way Anova, Tukey post test of Graphpad Prism 6.0.

\subsection{Confocal microscopic evaluation}

In order to determine the cytotoxic effects of escin on the morphology of Du-145 cells firstly were seeded on coverslips in six-well plates and were treated with the $\mathrm{IC}_{50}$ value of escin for 24 hours. After the incubation cells were fixed with glutaraldehyde and double-stained with phalloidin and acridine orange. Stained cells were imaged under a confocal microscope (Leica, TCS SP5 II, Germany).

\subsection{Annexin-V staining}

The induced cell death mode by escin on Du-145 cells was evaluated by Annexin-V staining technique. Firstly, control and escin-treated Du-145 cells were harvested in separate tubes (100 $\mu \mathrm{L} /$ tube). $100 \mu \mathrm{L}$ of Annexin-V dye was added to the tubes. All samples were incubated for 20 minutes at room temperature in dark. Cells were analyzed by 
using Muse ${ }^{\mathrm{TM}}$ Cell Analyzer (Merck, Millipore, Hayward, California, USA). This test was performed following the instructions of user manual of Muse ${ }^{\circledR}$ Annexin-V and Dead Cell Assay Kit.

\section{Results}

\subsection{SRB findings}

Cytotoxicity investigation was performed by usinf SRB viability test. SRB findings indicate the half maximal inhibitory concentrations of escin on Du-145 human prostate cancer cells for 24 hours of application. The viability of Du-145 cells found to be decreased by concentration dependent manner. The $\mathrm{IC}_{50}$ value of escin on Du-145 cells was detected as $30,48 \mu \mathrm{M}$. Statistically significant decrease on cell viability was detected on 100, 50, 25 and $12.5 \mu \mathrm{M}$ escin concentrations for short-term application of 24 hours (Figure 1).

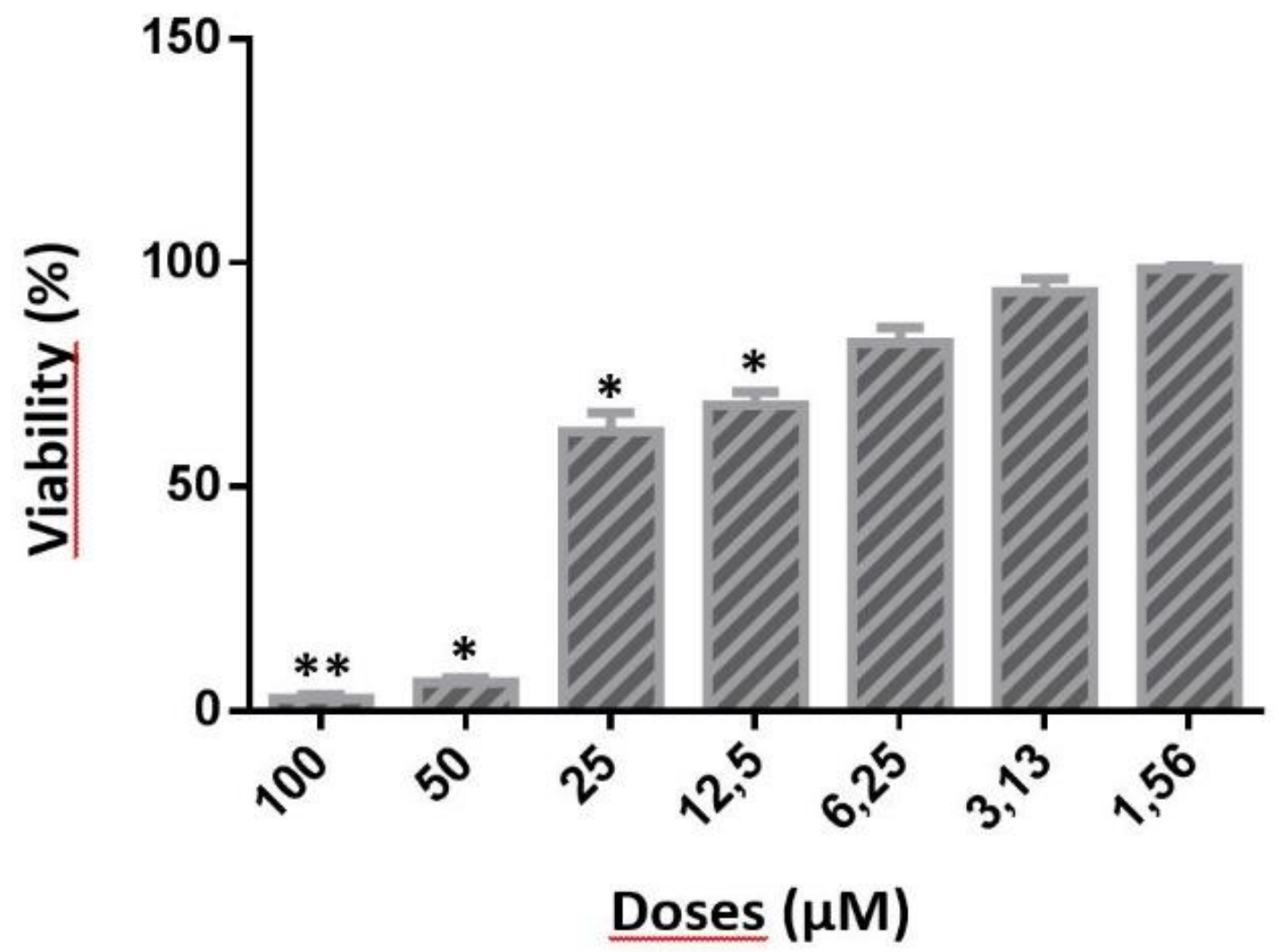

Figure 1: Viability percentages of Du-145 cells exposed to different escin concentrations for 24 hours. $\mathrm{IC}_{50}$ value of escin on Du-145 cells for 24 hours was detected to be $30,48 \mu \mathrm{M}$

\subsection{Confocal microscopy findings}

Confocal micrsocopy evaluations indicated significant changes on cell morphology of Du-145 cells exposed to the $\mathrm{IC}_{50}(30,48 \mu \mathrm{M})$ concentration of escin for 24 hours. Compared to the control cell that were not treated with escin, test cells were found with altered morphology. Detected changes on Du-145 cell exposed to escin were holes on cytoskeleton, apoptotic cell shape (shrinked and with blebbings on cell membranes) and chromatin condensation (Figure 2). 

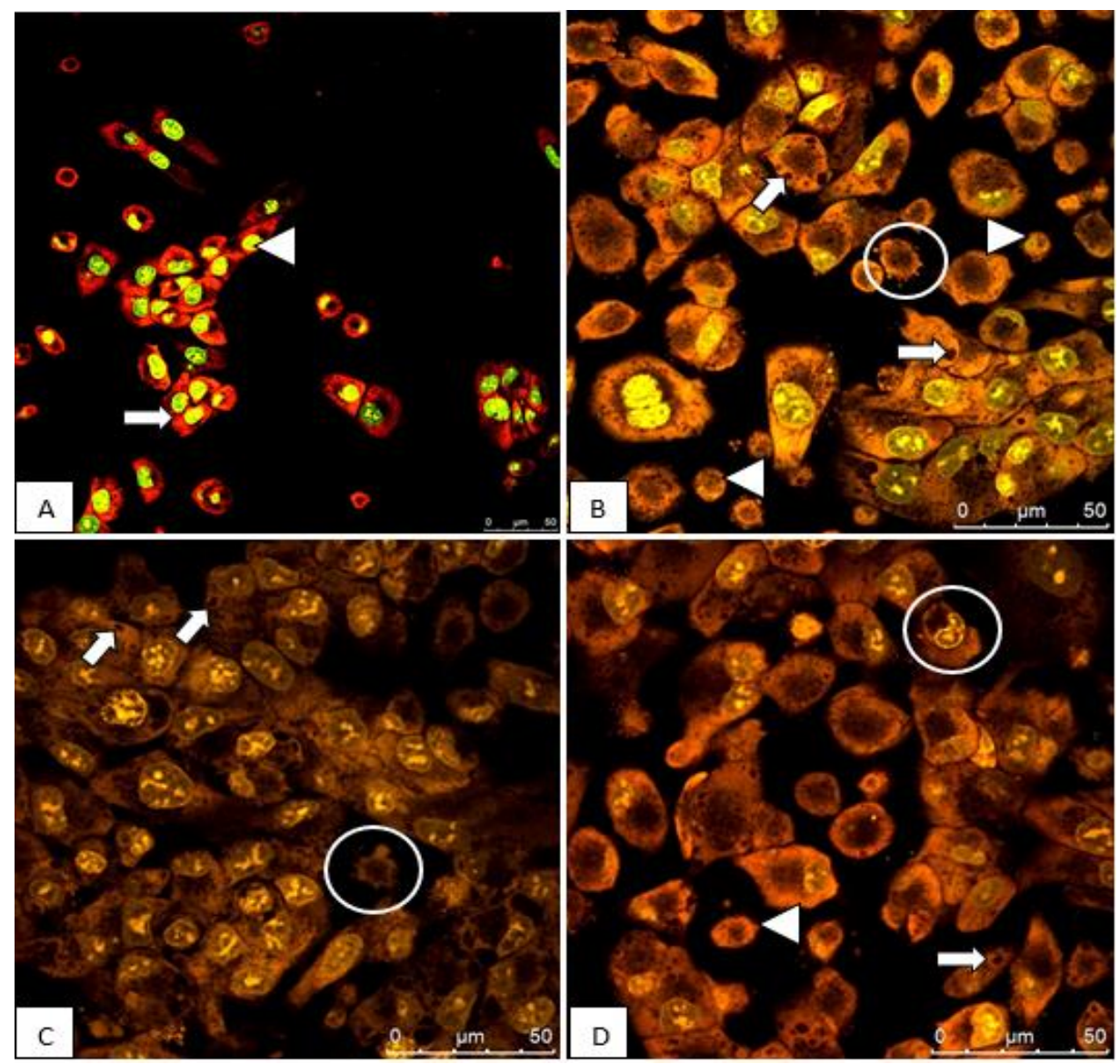

Figure 2: A. Untreated Du-145 cells: Arrow-Cytoskeleton, Arrowhead nucleus B, C, D. Morphological changes of Du145 cells exposed to $\mathrm{IC}_{50}$ value of escin for 24 hours. Arrow-holes on cytoskeleton, circle-apoptotic cell shape, arrowhead-shrunken cells.

\subsection{Annexin-V staining results}

Apoptotic profile of Du-145 cells was evaluated with Annexin-V technique. In the profile of Du-145 control cells the percentages were detected to be $95.70 \%, 3.57 \%$, and $0.73 \%$ for live, early apoptotic and late apoptotic cells, respectively. These percentages for Du-145 cells exposed to $\mathrm{IC}_{50}$ value of escin for 24 hours were determined as $61.60 \%, 30.05 \%$ and $8.2 \%$, respectively for live, early apoptotic and late apoptotic cells (Figure 3). The trigered cell death mode by escin on Du-145 human prostate cancer cells was detected to be apoptosis.
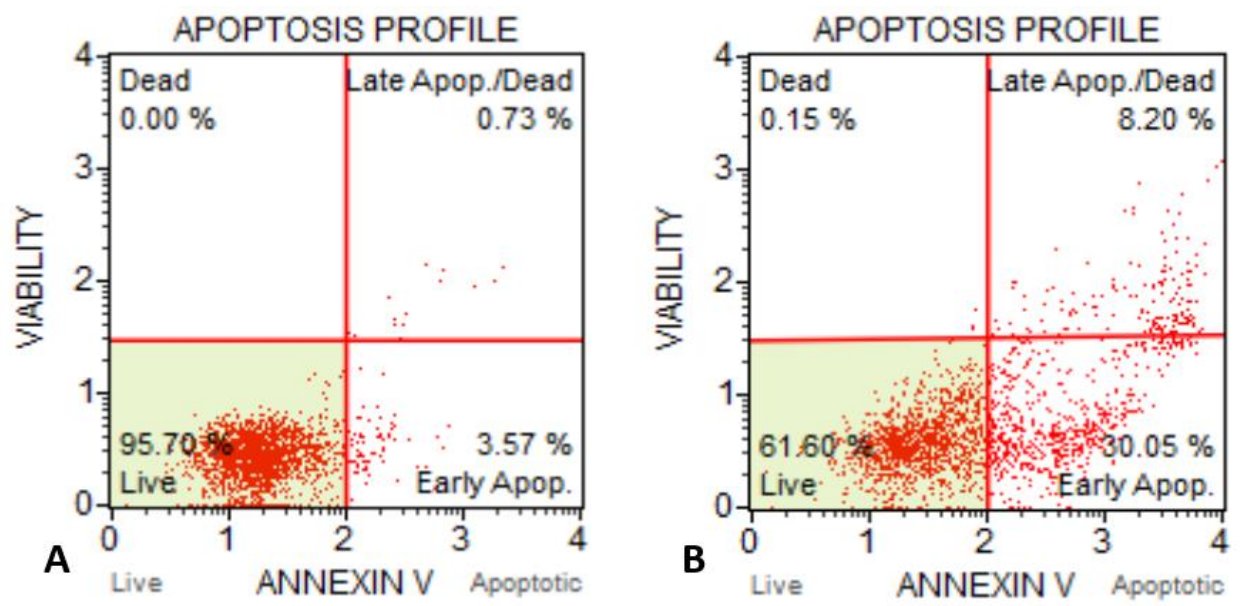

Figure 3: Apoptotic profiles of control (A-Live cells $95.70 \%$, Early apoptotic cells 3.57\%, Late apoptotic cells $0.73 \%$ ) and Du-145 cells exposed to $\mathrm{IC}_{50}$ value of escin for 24 hours (B-Live cells $61.60 \%$, Early apoptotic cells $30.05 \%$, Late apoptotic cells $8.2 \%$.). 


\section{Conclusions and discussion}

Escin showed its toxicity on Du-145 cells by causing growth inhibition in a dose dependent manner in shortterm application of 24 hours. The viability of $\mathrm{Du}-145$ cells treated with escin was decreased with the increase in applied escin concentration. Highest growth supress was recorded at the highest dose of escin. In addition significant antiproliferative activity of escin was detected on dose range 100-12.5 $\mu \mathrm{M}$ (Figure 1). The $\mathrm{IC}_{50}$ value of escin on human prostate cancer Du-145 cells was found to be $30.48 \mu \mathrm{M}$. Studies conducted on different cell lines as human lung adenocarcinoma, pancreatic cancer, Jurkat, HepG2, C6, H-Ras 5RP7 cells reported the antiproliferative effect of escin [13-16]. Along with the growth inhibitory effect, escin has been reported to have proapoptotic activity on numerous studies $[13,17]$. In this study, it was showed that escin induced apoptosis on Du- 145 cells at its $\mathrm{IC}_{50}$ concentration. This activity was indicated firstly based on the morphological changes detected after escin treatment for 24 hours. The results indicated that untreated Du-145 cells were with unchanged and compact morphology whereas escin treated cells were with significant alterations that were considered as stong indicators of apoptosis. These changes were cell shinkage, membrane blebbings, chromatin condensation and holes on cytoskeleton of Du-145 cells (Figure 2). Investigations on escin based cell death mechanisms reported apoptosis to be the induced cell death type [13-15]. Natural product and their potential usage in cancer treatment was investigated by different studies and results imply to the strong basis of natural products and escin for new therapeutics [17]. The findings considered apoptosis to be prefered cell death mode induced by agents with anticancer potential [18, 19]. Based on the data, in this study we investigated apoptotic profiles of Du-145 cells treated with escin for 24 hours. Apoptotic profiles of control cells showed that $95.70 \%$ of Du-145 cells were alive, whereas approximately $4 \%$ of these cells underwent apoptosis. The percentage of viable cells in Du-145 cells exposed to $\mathrm{IC}_{50}$ concentrations of escin for 24 hours was reduced to $61.60 \%$ and the percentage of total apoptotic cells was detected to be approximately $38 \%$ (Figure 3). Escin caused early apoptosis in Du-145 cells at a percentage of $30.05 \%$ and late apoptosis at $8.2 \%$. The trigered apoptosis type nd apoptotic death stage by escin, have reported to be concentration and cell type dependent [9]. This imply to the information that the detected $\mathrm{IC}_{50}$ value of escin in Du- 145 cells have caused early apoptosis significantly but the case with other escin concentrations required to be investigated. All investigation results of this study confirm the cytotoxic, antiproliferative and proapoptotic activities of escin on Du-145 human prostate cancer cells. Consequently, escin can be proposed for drug designing studies with all theranostic capabilities for cancer therapy agent.

\section{References}

[1] Sirtori, C. R. (2001). Aescin: pharmacology, pharmacokinetics and therapeutic profile. Pharmacol. Res., 44, 183-193.

[2] Gallelli, L. (2019). Escin: a review of its anti-edematous, anti-inflammatory, and venotonic properties. Drug. Des. Devel. Ther.,13, 3425-3437.

[3] Bombardelli, P. M. \& Griffini, A. (1996). Aesculus hippocastanum L. Fitoterapia, 67 (6), 483-511.

[4] Matsuda, H., Li, Y. \& Yoshikawa, M. (2000). Possible involvement of 5-HT and 5-HT2 receptors in acceleration of gastrointestinal transit by escin Ib in mice. Life Sci. 66, 2233-2238.

[5] Satoh, S., Kreutz, R., Wilm, C., Ganten, D. \& Pfitzer, G. (1994). Augmented agonist-induced Ca(2p)sensitization of coronary artery contraction in genetically hypertensive rats. Evidence for altered signal transduction in the coronary smooth muscle cells. J. Clin. Investig. 94, 1397-1403.

[6] Facino, R. M., Carini, M., Stefani, R., Aldini G. \& Saibene, L. (1995). Anti-elastase and antihyaluronidase activities of saponins and sapogenins from Hedera helix, Aesculus hippocastanum, and Ruscus aculeatus: factors contributing to their efficacy in the treatment of venous insufficiency. Arch. Pharmazie 328, 720-724.

[7] Cengiz, M., Ayhanc1, A. \& Kutlu, H. M. (2020). Investigation into the protective effects of escin on blood cells and cyclophosphamide-induced bone marrow toxicity in rats. BŞEÜ Fen Bilimleri Dergisi. 7 (2): $730-738$.

[8] Waller, G. R. \& Yamasaki, K. (1996). Saponins Used in Traditional and Modern Medicine. 1 ed., Springer, Boston, MA.

[9] Cheong D. H. J., Arfuso, F. \& Sethi, G. (2018). Molecular targets and anti-cancer potential of escin. Cancer Letters 422: 1-8.

[10] Gür, F., Cengiz, M., Kutlu, H. M., Cengiz, B. P. \& Ayhanc1, A. (2021). Molecular docking analyses of Escin as regards cyclophosphamide-induced cardiotoxicity: In vivo and in Silico studies. Toxicol. Appl. Pharmacol., 411:115386.

[11] Allen, D. J. \& Khela, S. (2017). Aesculus hippocastanum. The IUCN Red List of Threatened Species, e.T202914A68084249.

[12] Snieškienè, V., Baležentienè, L. \& Stankevičienè, A. (2011). State of horse-chestnut, Aesculus hippocastanum L., in Lithuania: diseases and pest damages. Ekologija., 57, 62-69. 
[13] Güney, G., Kutlu, H. M. \& Iscan, A. (2013). The apoptotic effects of escin in the H-Ras transformed 5RP7 cell line. Phytother Res. 27, 900-905.

[14] Çiftçi, G. A., Iscan, A. \& Kutlu H. M. (2015). Escin reduces cell proliferation and induces apoptosis on glioma and lung adenocarcinoma cell lines. Cytotechnology., 67, 893-904.

[15] Wang, Y. W., Wang, S. J., Zhou, Y. N., Pan, S. H. \& Sun, B. (2012). Escin augments the efficacy of gemcitabine through down-regulation of nuclear factor-kB and nuclear factor-kB-regulated gene products in pancreatic cancer both in vitro and in vivo. J. Canc. Res. Clin. Oncol., 138, 785-797.

[16] Ming, Z. J., Hu, Y., Qiu, Y. H., Cao, L. \& Zhang, X. G. (2010). Synergistic effects of [beta]-aescin and 5fluorouracil in human hepatocellular carcinoma SMMC-7721 cells. Phytomedicine: Int. J. Phytother. Phytopharm., 17, 575.

[17] Cengiz, M., Kutlu, H. M., Peker Cengiz, B. \& Ayhanc1, A. (2020). Escin attenuates oxidative damage, apoptosis and lipid peroxidation in a model of cyclophosphamide-induced liver damage. Drug. Chem. Toxicol., 24:1-8.

[18] Deorukhkar, A., Krishnan, S., Sethi, G. \& Aggarwal, B. B. (2007). Back to basics: how natural products can provide the basis for new therapeutics. Expet. Opin. Invest. Drugs., 16, 1753-1773.

[19] Erdoğan, M. K., Ağca, C. A. \& Geçibesler, İ. H. (2020). The antiproliferative potential of isolated emodin and aloe-emodin from Rheum ribes on different cancer cell lines. Biological Diversity and Conservation, 31(2): 160-168. 